УДК 37.015.31:796:37.091.4Ушинський(045)

\title{
МЕТОДИЧНІ ЗАСАДИ ФІЗИЧНОГО ВИХОВАННЯ ШКОЛЯРІВ У ПЕДАГОГІЧНІЙ СПАДЩИНІ КОСТЯНТИНА УШИНСЬКОГО
}

\author{
Сергій Марчук ${ }^{1}$ \\ ${ }^{1}$ Луцький педагогічний коледж, Луцьк, Україна, \\ Marchuk_Serhiy_Step_2701@ukr.net \\ https://doi.org/10.29038/2220-7481-2020-01-29-35
}

\begin{abstract}
Анотації
Bcmyn. У статті розкрито педагогічні засади фізичного виховання в науковій спадщині видатного українського педагога, корифея світової й вітчизняної психолого-педагогічної науки Костянтина Ушинського. Мета дослідження - проаналізувати методичні засади фізичного виховання школярів крізь призму розгляду педагогічних засобів і форм у гуманістичній та здоров'язберігальній концепції Ушинського. Методи дослідження вивчення літературних джерел, документальних матеріалів, теоретичний аналіз і синтез отриманих даних. Результати дослідження. На основі вивчення історико-літературних джерел установлено, що К. Ушинський (1824-1870) критично порівняв освітні реалії зарубіжжя з актуальним станом вітчизняної школи та зробив вагомі теоретичні узагальнення щодо таких актуальних методичних питань фізичного виховання: місця гімнастики й гімнастичних ігор у змісті навчальних предметів у школах різного типу; впливу режиму дня на нормальний фізичний розвиток вихованців; ролі раціонального харчування в збереженні здоров'я учнів; формування сприятливого психоемоційного клімату та ін. Висновки. Дослідження, здійснене на основі історико-педагогічного аналізу праць К. Ушинського, дало змогу виокремити та зафіксувати арсенал засобів фізичного виховання школярів у творчій спадщині видатного педагога: фізичні вправи, гімнастика, гра, праця, ознайомлення учнів із теоретичними відомостями з анатомії, фізіології та гігієни в підручниках «Дитячий світ» і «Рідне слово»; природні й гігієнічні чинники: раціональний режим праці, харчування, відпочинок, сон. Визначено найбільш дієві організаційні форми фізичного виховання учнів у науковому доробку К. Ушинського: уроки гімнастики, фізкультурні хвилинки, фізкультурні паузи, раціональна організація відпочинку учнів на перервах, на свіжому повітрі 3 рухливими іграми, прогулянками на природу. Загальнопедагогічні положення К. Ушинського істотно вплинули на теорію фізичного виховання царської Росії другої половини ХІХ ст. Як українського педагога, Костянтина Ушинського, без сумніву, можна вважати засновником національної педагогічної теорії фізичного виховання.

Ключові слова: фізичне виховання, засоби фізичного виховання, форми фізичного виховання, педагогічна спадщина, К. Ушинський.

Сергей Марчук. Методические принципы физического воспитания школьников в педагогическом наследии Константина Ушинского. Введение. В статье раскрываются педагогические принципы физического воспитания в научном наследии выдающегося украинского педагога, корифея мировой и отечественной психолого-педагогической науки Константина Ушинского. Цель исследования - проанализировать методические принципы физического воспитания школьников сквозь призму рассмотрения педагогических средств и форм в гуманистической и здоровьесберегающей концепции Ушинского. Методы исследования - изучение литературных источников, документальных материалов, теоретический анализ и синтез полученных данных. Peзультаты исследования. На основе изучения историко-литературных источников установлено, что К. Ушинский (18241870) критически сравнил образовательные реалии зарубежья с актуальным состоянием отечественной школы и сделал весомые теоретические обобщения относительно таких актуальных методических вопросов физического воспитания: места гимнастики и гимнастических игр в содержании учебных предметов в школах разного типа; влияние режима дня на нормальное физическое развитие воспитанников; роли рационального питания в сохранении здоровья учеников; формирование благоприятного психоэмоционального климата и др. Выводы. Исследование, осуществленное на основе историко-педагогического анализа трудов К. Ушинского, дало возможность выделить и зафиксировать арсенал средств физического воспитания школьников в творческом наследии выдающегося педагога: физические упражнения, гимнастика, игра, труд, ознакомление учеников с теоретическими сведениями из анатомии, физиологии и гигиены в учебниках «Детский мир» и «Родное слово»; естественные и гигиенические факторы: рациональный режим труда, питания, отдых, сон. Определяются наиболее действенные организационные формы физического воспитания учеников в научном учении К. Ушинского: уроки гимнастики, физкультурные минутки, физкультурные паузы, рациональная организация отдыха учеников на переменах, на свежем воздухе с подвижными играми, прогулками на природу. Общепедагогические положения К. Ушинского существенно повлияли на теорию физического воспитания царской России второй половины XIX в. Как украинского педагога, Константина Ушинского, без сомнения, можно считать основателем национальной педагогической теории физического воспитания.
\end{abstract}


Ключевые слова: физическое воспитание, средства физического воспитания, формы физического воспитания, педагогическое наследие К. Ушинский.

Serhii Marchuk. Methodical Principles of Pupils' Physical Education in Kostiantyn Ushynskyi Pedagogical Heritage. Introduction. The pedagogical principles of Physical Education in the scientific heritage of the prominent Ukrainian teacher Kostiantyn Ushynskyi have been described. The purpose of the study is to analyze the methodological foundations of pupils' PE through the prism of consideration of pedagogical means and forms in the humanistic and health-saving of K. Ushynskyi`s concept. Research methods such as the study of literary sources, theoretical analysis and synthesis of the obtained data were used in the paper. Research Results. On the basis of the historical and literary sources, it was found that K. Ushynskyi (1824-1870) critically compared the educational realities of foreign countries and the current state of the national school and made significant theoretical generalizations about such actual methodical issues on physical education as: the place of gymnastics and gymnastic games in the content of educational subjects; formation of favorable psycho- emotional climate and other. Conclusions. The research, carried out on the basis of the historical and pedagogical analysis of K. Ushynskyi's scientific papers, made it possible to isolate and fix the means of pupils' physical education in the creative heritage of an outstanding teacher: gymnastics, game, work, pupils' acquaintance with theoretical information on anatomy, physiology and hygiene from the «Children's World» and «Native Word» textbooks. The most effective organizational forms of pupils' physical education in K. Ushynskyi's scientific work are defined: gymnastics lessons, physical training minutes, physical training pauses, and rational organization of pupils' rest during breaks, including moving games and walks outdoors. The general pedagogical provisions of K. Ushynskyi significantly influenced the PE theory of $\mathrm{t}$ Russia in the second half of the $19^{\text {th }}$ century. As a Ukrainian educator, Kostiantyn Ushynskyi can undoubtedly be considered as the founder of the national pedagogical Theory of Physical Education.

Key words: Physical Education, means of Physical Education, forms of Physical Education, pedagogical heritage, K. Ushynskyi.

Вступ. Важливим аспектом педагогічної науки, спрямованої на формування теоретичних i практичних засад національного виховання школярів, є вивчення й узагальнення вітчизняного та світового педагогічного досвіду фізичного виховання дітей і молоді, оскільки наукове розв'язання сучасних освітніх проблем неможливе без знання педагогічної спадщини минулого. Актуальні думки щодо теорії й практики фізичного виховання залишив нам у спадок славетний український педагог XIX ст. Костянтин Ушинський (1824-1870).

Наукову творчість К. Ушинського грунтовно досліджували та популяризували українські вчені Л. Березівська [1], Г. Костюк [4], М. Носко [3], Д. Скільський [5], О. Сухомлинська [6], а також зарубіжні науковці Р. Мітценхайм [18], Н. Ханс [19], Й. Петерсен, Н. Петерсен [20]. Погляди Ушинського щодо фізичного виховання вивчали С. Марчук [2], А. Цьось, Т. Чирва [17] та ін.

Мета дослідження - проаналізувати наукову спадщину видатного українського вченого К. Ушинського й визначити методичні засади фізичного виховання школярів крізь призму розгляду педагогічних засобів і форм у гуманістичній та здоров'язберігальній педагогіці Ушинського. Методи дослідження - вивчення літературних джерел, документальних й історичних матеріалів, теоретичний аналіз і синтез отриманих даних.

Результати дослідження. Костянтин Ушинський у свої творах «Педагогічна подорож Швейцарією», «Педагогічні замітки про Швейцарію», «Звіт про відрядження за кордон», «Програма педагогіки для спеціальних класів жіночих навчальних закладів», «Дещо про перші уроки в школі», «Праця в їі психічному і виховному значенні», підручниках «Дитячий світ» та «Рідне слово» визначає дієві форми й засоби фізичного виховання школярів. Педагог великого значення надає ознайомленню школярів із теоретичними відомостями в галузі анатомії, фізіології та гігієни. Він вважає, що правила фізичного виховання $є$ лише тоді позитивними, точними й правильними, коли грунтуються на глибокому знанні анатомії та фізіології [8, с. 33].

На перших сторінках «Педагогічної антропології» автор визначає важливу роль окремих засобів фізичного виховання (гімнастики, гігієни харчування, дотримання оптимального температурного режиму навчальних приміщень). Під час вивчення теоретичних основ фізичного виховання пропонує слухачкам ознайомлюватися з нормами температури повітря, світла, харчування. Педагог у «Програмі 3 педагогіки для спеціальних класів жіночих навчальних закладів» розгортає актуальність таких тем: «Вплив свіжого повітря, купання, гімнастики, раціонального способу життя на дітей», «Вплив розумової і фізичної роботи на нервову систему», «Необхідність реального відпочинку в нервовій діяльності», «Сон, його фізіологічне значення, тривалість залежно від віку» [11, с. 26].

Детальне вивчення та науковий аналіз праць К. Ушинського дають підставу окреслити певний перелік тематичних статей щодо певних засобів фізичного виховання: «М'язи», «Фізична теорія 
тілесних рухів», «Потреба відпочинку і сну», «Нервова втома і нервове напруження», «Воля як влада душі над тілом», «Виховне значення дитячих ігор», «Праця в її психічному і виховному значенні» та ін.

Історико-педагогічний аналіз творчої спадщини К. Ушинського дав змогу виокремити та зафіксувати систему засобів фізичного виховання школярів у науковому спадку педагога: фізичні вправи (педагог їх позначає терміном «тілесні» вправи»): гімнастичні вправи, гімнастика, гра, гімнастичні ігри; ознайомлення учнів із теоретичними відомостями в галузі анатомії, фізіології та гігієни, викладеними в підручниках «Дитячий світ» та «Рідне слово»; природні фактори (сонце, повітря, вода); гігієнічні чинники (раціональний режим праці, харчування, відпочинку, сну); фізична праця, сільськогосподарські роботи; самовиховання як важливий фактор формування здорової особистості.

Науково-педагогічний аналіз праць К. Ушинського [7-16] дав змогу виділити в його творчій спадщині такі організаційні форми фізичного виховання: уроки (заняття) гімнастики (урочні форми), фізкультхвилинки, фізкультпаузи; організація відпочинку учнів на перервах, на повітрі з рухливими іграми (форми в режимі навчального дня школи), прогулянки в сад, поле, ліс та ін. (позакласні форми роботи).

Гімнастику, гімнастичні вправи, гімнастичні ігри К. Учинський розглядає як основні засоби та форми фізичного виховання. Науковець аналізує педагогічне та лікувальне значення гімнастики, визначає зміст гімнастичних вправ, їх тривалість під час уроку. Костянтин Дмитрович описує досвід застосування гімнастичних занять у зарубіжних навчальних закладах, учительських семінаріях, пропонує прогресивні ідеї покращення викладання гімнастики у вітчизняній школі. Учений відзначає, що «недалеко той час, коли гімнастика стане наймогутнішим медичним засобом навіть при складних внутрішніх хворобах; гімнастичне лікування спрямовує фізичні сили організму на певний орган тіла, а воля змінює тіло або виліковує його недуги» [8, с. 38]. Педагог поділив гімнастику на розумову та фізичну. Гімнастика розуму - це формальний розвиток пам'яті та мислення. Для того, щоб така гімнастика не завдавала шкоди, потрібно свідомо засвоювати матеріал. Фізична гімнастика, на думку науковця, - це вправи для м'язів і зміцнення нервової системи.

Положення К. Уиинського обтрунтовують виховну, розвивальну, оздоровчу роль ігор для фізичного та духовного розвитку особистості: уважно стежте за іграми дитини, вона тут виявляє свій духовний світ; для дитини гра - дійсність; у грі вона живе, пробує свої сили й самостійно керує своїми фантазіями; ігри провіщають майбутнє дитини; у ранньому віці гра має більше значення для розвитку дитини, ніж навчання; під час колективних ігор виникають перші асоціації з громадськими відносинами; дитині, яка звикла командувати або підкорятися в грі, нелегко відучитися від цього в дійсності [8, с. 296-297]. Грунтовний аналіз наукового спадку німецького педагога Ф. Фребеля дав підставу К. Ушинському сформулювати такі педагогічні висновки щодо гри:

- гра є вільною діяльністю дитини; у ній формуються всі сторони людської душі (розум, серце, воля);

- ігри передбачають майбутній характер і долю дитини; сама гра має великий вплив на розвиток дитячих здібностей та нахилів;

- вихователь має великий вплив на гру дитини (навчаючи ії гри, підбираючи товаришів, даючи ідею ігор, засоби для виконання дитячих фантазій, припиняючи гру, якщо вона шкідливо впливає на дитину);

- дитячі ігри мають свої національності й власну багатовікову історію;

- велику послугу справі виховання зробив би той педагог, який би вивчив докладно якнайбільшу кількість дитячих ігор і, випробувавши їх на практиці з дітьми, проаналізував би їх психічний вплив на дитячі характери;

- діти безперестанно творять нові ігри, пристосовуючись до місцевості, речей, обставин, дня; у певній грі дитина зазнає труднощів і страждань у зв'язку з тією душевною діяльністю, яку дає гра (що в дорослому житті забезпечуватиме ії життєве щастя) [12, с. 332].

Актуальною, на нашу думку, виявилася така думка К. Ушинського: «Ми надаємо такого великого значення дитячим іграм, що коли б влаштовували вчительську семінарію, чоловічу чи жіночу, то зробили б теоретичне й практичне вивчення дитячих ігор одним із головних предметів» [12, с. 333].

К. Уиинський ваэжливого значення надає ознайомленню учнів із теоретичними відомостями 3 галузі анатомії, фізіології та гіхієни, викладеними в авторських підручниках "Дитячий світ» та «Pідне слово». Науковий інтерес викликають методичні статті й матеріали К. Ушинського до першого видання «Дитячого світу» (1861). Автор подає відомості про людину, іiі організм, духовну сферу. Зокрема, у другому розділі «Про людину» педагог помістив 20 пізнавальних статей: «П’ять зовнішніх 
чуттів», «Речовини, що складають тіло людини», «Головні частини людського тіла», «Рука і нога», «Голова», «Очі», «Вуха», «Ніс», «Рот», «Внутрішні органи людського тіла», «Харчування», «Мозок i нерви», «Кістки», «Властивості душі», «Створення людини» та ін. [7, с. 41-42]. Зазначимо, що в змісті запропонованих рекомендацій автор подає короткі поради вчителеві до вивчення різних тем на уроці. Наприклад, «Описи частин людського тіла повинні супроводжуватися спогляданням. Дуже корисно показувати при цьому малюнки, якщо вони $\epsilon$, ще корисніше було, коли б учні змогли самостійно зобразити той предмет, про який прочитали» [7].

К. Ушинський у статтях до першого видання «Дитячого світу» пропонує цікаві валеологічні поради школярам:

- «Чим міцніші м'язи, тим сильніші наші органи. Щоб зробити м'язи міцнішими, потрібно часто і багато виконувати вправ. У лінивих, хто не любить ні ходити, ні працювати, м'язи в'ялі, м'які, органи слабші, нерухливі і швидко втомлюються» (стаття «Рука і нога») [7, с. 96].

- «Для ока шкідливе надто сильне і довготривале напруження зору. Не потрібно тримати книгу чи зошит ні дуже близько, ні занадто далеко від очей - це шкідливо. Не можна дивитись на сонце, яскраве полум'я, на снігові поля при яскравому сонячному освітленні. Приємно та корисно для очей дивитися на предмети зеленого кольору. Потрібно тримати очі в чистоті, ретельно промивати їх вранці холодною водою. Не потрібно витирати очі брудним рушником і брудною рукою» (стаття «Очі») [7, с. 99-100].

- «Ковтати їжу шматками дуже шкідливо. Розкушування твердих предметів псує зуби, при цьому часто тріскається емаль» (стаття «Рот») [7, с. 103].

- «Як мудро створена людина! Наука, що вивчає будову всіх органів людського тіла, називається анатомією; наука, що показує, як кожен із цих органів виконує свою роботу і як всі органи разом дають людині можливість харчуватися, відчувати, рухатися, називається фізіологією. Дві ці науки необхідні для медика, який повинен знати як влаштоване і як функціонує людське тіло, щоб мати можливість допомогти йому у випадку хвороби певного органу» (стаття «Кістки») [7, с. 115-116].

У підручнику «Рідне слово» (для першого року навчання) педагог визначив окремі уроки, на яких учні здобувають знання з анатомії, фізіології, гігієни людини, а також отримують корисні поради для зміцнення власного здоров'я. Часто пропоновані матеріали, регламентовані темами уроків, супроводжуються народними загадками, прислів'ями, скоромовками. У методичних матеріалах до «Дитячого світу» автор пропонує вчителеві раціональні прийоми проведення «Бесіди про людину з використанням письмових вправ та таблиць» [16, с. 288-291].

К. Уиинський аналізує важсливі природні чинники фізичного виховання - сонце, повітря, воду, що діють спільно з фізичними вправами (гімнастикою, іграми) і посилюють оздоровчий вплив на учнів. Він удало підкреслив важливу роль природи у фізичному розвитку особистості: «Уявіть собі дитину в якомусь глухому сільському закутку, що бавиться цілий день під впливом усерозвиваючої природи, невпинно рухається, відчуває, думає, по-дитячому, звичайно, плаче або сміється, тобто живе всім своїм духовним і тілесним організмом [16, с. 409]. На думку педагога, природа є одним із наймогутніших «агентів» у вихованні людини, і без неї воно буде проникнуте сухістю, однобічністю, неприємною штучністю. Гігієнічні чинники, визначені К. Ушинським, охоплюють гігієнічне забезпечення раціонального режиму праці, харчування, відпочинку, сну.

Фізичну працю К. Учинський визначає як дієвий засіб зміцнення здоров'я школярів. Найбільш повно цю важливу проблему педагог дослідив у творі «Праця в ії психічному та виховному значенні»: тіло, серце й розум людини потребують праці [10, с. 389-390]; саме праці людина була зобов'язана хвилинами високих насолод [10, с. 389-391]. На нашу думку, Ушинський влучно розкрив призначення праці в житті людини: «Творець зробив працю необхідною умовою фізичного, морального і розумового розвитку, і саме щастя й гідність людини зробив залежним від особистої праці» [10, с. 395]. Педагог обгрунтовує працю як життєвий та здоров'язберігальний принцип: фізична праця потрібна для розвитку й підтримання в тілі людини фізичних сил, здоров'я, фізичних здібностей; необхідність розумової праці для розвитку сил і здорового, нормального стану людського тіла є очевидною; надмірна розумова праця шкідлива; але й надмірна фізична праця також по-руйнівному впливає на організм; будь-яка розумова праця впливає благотворно на обіг крові та травлення [10, с. 390]. Відпочинок після розумової праці полягає не в тому, щоб нічого не робити, а в тому, щоб змінити роботу: праця фізична не лише приємний, а й корисний відпочинок після праці розумової [14, с. 119].

Самовиховання виступає важливим чинником формування здорової особистості в педагогічній концепції К. Ушинського. У статті «Педагогічні твори М. І. Пирогова» (1858) Костянтин Дмитрович пише: «Тільки той, хто зберіг у собі можливість кожної хвилини стояти віч-на-віч із власною 
душею, не відокремлюючись від неї жодними упередженнями, жодною звичкою, що вкоренилася глибоко і $є$ несвідомою; тільки той, хто не торгується із самим собою і готовий завжди, у цілісності власної душі, зважитися на щось безоглядно, без прихованих, не виявлених назовні, почуттів, без обманливих фраз, - тільки той здатний іти шляхом самовдосконалювання і вести ним інших» [15, с. 286].

У «Щоденнику університетських років» Ушинський-студент визначає мету самовиховання, фіксує засоби та методи іiі досягнення, описує власні емоції й почуття. Заслуговує на увагу, на нашу думку, «рецепт» самовиховання Костянтина Ушинського: 1. Спокій цілковитий, принаймні, зовнішній. 2. Прямота в словах і вчинках. 3. Обдуманість дій. 4. Рішучість. 5. Не говорити про себе без потреби жодного слова. 6. Не марнувати часу несвідомо; робити те, що хочеш, а не те, що трапиться. 7. Витрачати лише на необхідне або приємне, а не за пристрастями. 8. Кожен вечір добросовісно давати собі звіт у вчинках. 9. Жодного разу не хвалитися ні тим, що було, ні тим, що $\epsilon$, ні тим, що буде. 10. Нікому не показувати цього журналу [13, с. 413]. Цінною ознакою правильно вихованих волі й характеру $є$ сміливість, яку К. Ушинський трактує як життєву енергію людини, як відчуття людиною власних сил. Самовиховання є тим засобом, що допомагає змінити особистість, підготувати ії до реалізації життєвої програми. Запропонований «рецепт» самовиховання К. Ушинського, поза сумнівом, може слугувати моделлю формування особистості молодої людини в морально-вольовій сфері та зміцненні іiі духовного здоров'я.

К. Уиинський визначас оздоровчу роль фізкультхвилинок $\boldsymbol{i}$ фізкультпауз у відпочинку, підвищенні розумової працездатності школяра. Педагог у своїх статтях «Педагогічна практика», «Дещо про перші уроки в школі», «Праця в іiі психічному і виховному значенні» акцентує на розгляді цієї проблеми. К. Ушинський у власній педагогічній діяльності відразу помічав стомлювання учнів і для 15-хвилинного відпочинку практикував такі прийоми: розмова з дітьми про домашні справи, ігри, розказування анекдоту, ознайомлення 3 життєписом відомої людини [16, с. 302]. Отже, як бачимо, педагог описує важливість фізкультпаузи для відпочинку учнів.

У підручнику «Рідне слово» К. Ушинський радить учителям під час викладання рідної мови використовувати фізкультхвилинки, щоб запобігти неуважності та втомі школярів, переключити їх увагу 3 одного виду діяльності на інший, дати можливість короткочасного відпочинку дитячому організмові. Для цього педагог пропонує такі способи швидкої релаксації:

- привчити дітей до деяких класних рухів за командою, які корисні не тільки тому, що дають дітям змогу рухатися й розім'яти свої стомлені від сидіння органи, а й допомагають учителеві збуджувати увагу класу та зосереджувати на своїх словах та рухах;

- ці рухи мають бути нечисленні й прості: устаньте, сідайте, руки на стіл, руки назад, піднесіть праву руку, ліву, вийдіть із-за лав, перемініть місця, перша лава, устань, друга - сідай тощо; доцільно привчити дітей до певних рухів за німою командою - якимись умовними знаками;

- класні співи $є$ прекрасним засобом, що освіжає й гармонує клас; коли помітили, що клас стомився, неуважний, працює мляво, починаються позіхання, маленькі пустощі, попросіть проспівати якусь пісеньку - і все знову налагодиться, енергія відновиться, діти почнуть працювати, як перед тим; якщо вчитель не вміє співати, хай привчить дітей вимовляти цілим класом якісь молитви, вірші, прислів'я; це може замінити частково співи, як засіб, що освіжає стомлений і неорганізований клас [16, с. 403].

Прогулянки як рекреаційно-оздоровча позакласна форма фізичного виховання школярів. Перебуваючи за кордоном, К. Ушинський неодноразово спостерігав у зарубіжних школах цю сприятливу й найбільш природну для фізичного розвитку учнів форму занять. Так, у школі Фреліха в Берні він чекав на прихід директора закладу у форштегерській кімнаті й на свічниках побачив два вінки 3 альпійського моху. «Ці вінки без сумніву, принесли дівчатка зі своїх далеких прогулянок у гори. Пан Фреліх перший, здається, запровадив такі прогулянки в жіночі навчальні заклади, у чоловічих вони існують у Швейцарії вже давно» [9, с. 49]. Педагог висловлює думку про запровадження прогулянок у вітчизняні школи: «Непогано було б, якби й наших інституток водили хоч двічі на рік куди-небудь за місто, а жодна 3 них за 10 років кращої пори, коли саме розвивається любов до природи, що має чудовий вплив на розвиток людської душі, не побачить навіть польової квітки, не те що колосу жита» $[9$, c. $49-50]$.

Знання з історії та географії малої батьківщини є чистим і невичерпним джерелом, що живить патріотичні й національні почуття молоді, є могутнім зарядом духовності та моральності. К. Ушинський вважав, що знання про рідний край так само потрібні для духовного розвитку дитини, як уміння читати й писати. Цей інстинкт місцевості, наголошував видатний педагог, буває іноді сильною 
природженою здібністю, але часто його слід зміцнювати, розвивати, спрямовувати як здібність надзвичайно корисну і в навчанні, і в практичному житті.

Загалом, погоджуємося з думкою К. Ушинського, що гімнастика, різноманітні фізичні вправи, тілесна втома, що потребує сну та їжі, прогулянка на свіжому повітрі, прохолодна спальня, холодні купання $\epsilon$ найкращими засобами для того, щоб завжди тримати організм школяра в нормальному фізіологічному та психічному стані.

Висновки. Здійснений історико-педагогічний аналіз наукової спадщини К. Ушинського дав змогу виокремити й зафіксувати систему методичних засобів фізичного виховання школярів у творчому спадку педагога: фізичні вправи, гімнастика, гра, фізична праця, сільськогосподарські роботи, ознайомлення учнів із теоретичними відомостями 3 анатомії, фізіології та гігієни в підручниках «Дитячий світ» і «Рідне слово», природні та гігієнічні фактори - раціональний режим праці, харчування, відпочинку, сну. Аналіз праць К. Ушинського дав змогу виокремити низку організаційних форми фізичного виховання в його педагогічній спадщині, як-от: уроки гімнастики, фізкультурні хвилинки («руханки»), фізкультурні паузи; організація відпочинку учнів на перервах, на повітрі з рухливими іграми, прогулянки на природу. Загальнопедагогічні положення К. Ушинського істотно вплинули на теорію фізичного виховання царської Росії другої половини XIX ст. Як українського педагога, Костянтина Ушинського, без сумніву, можна вважати засновником національної педагогічної теорії фізичного виховання. Подальші наукові розвідки вбачаємо у творчому використанні ідей фізичного виховання в сучасній освітній практиці.

\section{Джерела та література}

1. Березівська Л. Д. Антропоцентризм - провідна ідея творчості основоположника наукової вітчизняної педагогіки К. Д. Ушинського. Педагогіка та психологія. 2013. № 3. С. 5-9.

2. Марчук С. С. Зарубіжний досвід фізичного виховання школярів у педагогічній спадщині К. Д. Ушинського. Педагогіка і психологія професійної освіти. 2011. № 4. С. 216-224.

3. Носко М. О. Розвиток педагогічної науки на Чернігівщині в руслі ідей К. Д. Ушинського. Педагогіка та психологія. 2013. № 3. С. 10-14.

4. Психологічна спадщина К. Д. Ушинського / за ред. Г. С. Костюка. Київ: Рад. шк., 1963. 234 с.

5. Скільський Д. М. Вчення К. Д. Ушинського про народність виховання. Педагогіка та психологія. 2012. № 3. C. 80-87.

6. Сухомлинська О. Педагогічна спадщина як предмет вивчення (на прикладі доробку К. Д. Ушинського). Шлях освіти. 2008. № 4. С. 37-41.

7. Ушинский К. Д. Собрание сочинений. Т. 5. Методические статьи и материалы к «Детскому миру» / ред. А. М. Еголин. Москва, Ленинград: Акад. пед. наук РСФСР, 1949. 591 с.

8. Ушинський К. Д. Людина як предмет виховання (спроба педагогічної антропології). Твори: в 6 т. Т. 4. Київ: Рад. шк., 1952. С. 21-454.

9. Ушинський К. Д. Педагогічна подорож Швейцарією. Твори: в 6 т. Т. 2 Київ: Рад. шк., 1954. С. 17-122.

10. Ушинський К. Д. Праця в іï психічному і виховному значенні. Твори: в 6 т.. Т. 5. Київ: Рад. шк., 1952. C. 387-395.

11. Ушинський К. Д. Програма педагогічного курсу для жіночих навчальних закладів. Твори: в 6 т. Т. 6 . Київ: Рад. шк., 1955. С. 16-38.

12. Ушинський К. Д. Стислий підручник педагогіки. Твори: в 6 т. Т. 6 Київ: Рад. шк., 1955. С. 237-402.

13. Ушинський К. Д. Вибрані педагогічні твори. Київ: Рад. шк., 1949. 418 с.

14. Ушинський К. Д. Вибрані педагогічні твори: у 2-х т. Т. 1: Теоретичні проблеми педагогіки. Київ: Рад. шк., $1983.496 \mathrm{c.}$

15. Ушинський К. Д. Твори: в 6-ти т. Т. 1: Педагогічні статті / відп. за укр. вид. Г. С. Костюк, С. Х. Чавдаров. Київ: Рад. шк., 1954. 449 с.

16. Ушинський К. Д. Твори: в 6-ти т. Т. 2: Педагогічні статті та матеріали до «Детского мира» та «Родного слова» / відп. за укр. вид. Г. С. Костюк, С. Х. Чавдаров. Київ: Рад. шк., 1954. 449 с.

17. Цьось А. В., Чирва Т. К. Актуальні питання фізичного виховання дітей (за працями Ушинського). Педагогіка і психологія. 2002. № 1-2. С. 198-203.

18. Mitzenheim P. Das pädagogische Erbe Ušinskijs. Seine Quelle der Sowjetpädagogik. Wissenschaftliche Zeitschrift der Friedrich-Schiller-Universität Jena. Gesellschaftswiss. R. 1988. Jg. 37. № 1. S. 97-101.

19. Hans N. K. D. Ushinski - Russian pioneer of comparative education. Comparative education Review. 1962. V. 5. N 3, February. P. 162-166.

20. Petersen J., Petersen N. K. D. Uschinskij (1824-1870) - ein grosser russischer Pädagoge. Erziehungskunst. 1997. Hf. 12. S. 1229- 1236. 


\section{References}

1. Berezivska, L. D. (2013). Antropotsentryzm - providna ideia tvorchosti osnovopolozhnyka naukovoi vitchyznianoi pedahohiky K. D. Ushynskoho [Anthropocentrism - the leading idea of creativity of K. D Ushinskyi`s scientific Pedagogy]. Pedahohika ta psykholohiia, no. 3, 5-9.

2. Marchuk, S. S. (2011). Zarubizhnyi dosvid fizychnoho vykhovannia shkoliariv u pedahohichnii spadshchyni K. D. Ushynskoho [PE`s foreign experience of schoolchildren in the pedagogical heritage of K. D Ushinskyi]. Pedahohika i psykholohiia profesiinoi osvity, no. 4, 216-224.

3. Nosko, M. O. (2013). Rozvytok pedahohichnoi nauky na Chernihivshchyni v rusli idei K. D. Ushynskoho [Development of pedagogical science in Chernihiv region in accordance to the ideas of K. D. Ushinskyi]. Pedahohika ta psykholohiia, no. 3, 10-14.

4. Psykholohichna spadshchyna K. D. Ushynskoho (1963). [Psychological heritage of K. D Ushinskyi]/Za red. H. S. Kostiuka (1963). Kyiv: Rad. shk., 234.

5. Skilskyi, D. M. (2012). Vchennia K. D. Ushynskoho pro narodnist vykhovannia [Ushinskyi`s studies on the national education]. Pedahohika ta psykholohiia, no. 3, 80-87.

6. Sukhomlynska, O. (2008). Pedahohichna spadshchyna yak predmet vyvchennia (na prykladi dorobku K. D. Ushynskoho) [Pedagogical heritage as a subject of study (on K. Ushinsky's research paper)]. Shliakh osvity, no. 4, 37-41.

7. Ushinskiy, K. D. (1949). Sobranie sochineniy [Collection of works. Methodical Papers to the «Children's World»]. Metodicheskie stati i materialyi k «Detskomu miru»/ red. A. M. Egolin. Moskva, Leningrad: Akad. ped. nauk RSFSR, T. 5., 591.

8. Ushynskyi, K. D. (1952). Liudyna yak predmet vykhovannia (Sproba pedahohichnoi antropolohii) [An invidious as a subject of education (Attempt at Pedagogical Anthropology)]. Tvory. V 6 t. T. 4. Kyiv: Rad. shk., 21-454.

9. Ushynskyi, K. D. (1954). Pedahohichna podorozh Shveitsariieiu [Pedagogical travel to Switzerland.]. Tvory. V 6 t. T. 2 Kyiv: Rad. shk., 17-122.

10. Ushynskyi, K. D. (1952). Pratsia v yii psykhichnomu i vykhovnomu znachenni [Work with its mental and educational significance]. Tvory. V 6 t. T. 5. Kyiv: Rad. shk., 387-395.

11. Ushynskyi, K. D. (1955). Prohrama pedahohichnoho kursu dlia zhinochykh navchalnykh zakladiv [The program of pedagogical course for women's educational institutions]. Tvory. V 6 t. T. 6. Kyiv: Rad. shk., 16-38.

12. Ushynskyi, K. D. (1955). Styslyi pidruchnyk pedahohiky [A brief textbook of Pedagogy]. Tvory. V 6 t. T. 6. Kyiv: Rad. shk., 237-402.

13. Ushynskyi, K. D. (1949). Vybrani pedahohichni tvory [Selected pedagogical compositions]. Kyiv: Rad. shk., 418.

14. Ushynskyi, K. D. (1983). Vybrani pedahohichni tvory [Selected pedagogical compositions]. U 2-kh t. T. 1. Teoretychni problemy pedahohiky. Kyiv: Rad. shk., 496.

15. Ushynskyi, K. D. (1954). Tvory [The compositions]. V 6-ty t. T. 1. Pedahohichni statti / vidp. za ukr. vyd. H. S. Kostiuk, S. Kh. Chavdarov. Kyiv: Rad. shk., 449.

16. Ushynskyi, K. D. (1954). Tvory [The compositions]. V 6-ty t. T. 2. Pedahohichni statti ta materialy do «Detskoho myra» ta «Rodnoho slova», vidp. za ukr. vyd. H. S. Kostiuk, S. Kh. Chavdarov. Kyiv: Rad. shk., 449.

17. Tsos, A. V., Chyrvam T. K. (2002). Aktualni pytannia fizychnoho vykhovannia ditei (za pratsiamy Ushynskoho) [Topical issues on Physical Education of children (according to Ushinsky`s research papers).]. Pedahohika $i$ psykholohiia, 1-2, 198-203.

18. Mitzenheim, P. (1988). Das pädagogische Erbe Ušinskijs. Seine Quelle der Sowjetpädagogik. Wissenschaftliche Zeitschrift der Friedrich-Schiller-Universität Jena. Gesellschaftswiss. R. 1988. Jg. 37, no. 1, 97-101.

19. Hans, N. (1962). K. D. Ushinski - Russian pioneer of comparative education. Comparative education Review, v. 5, N 3, February, 162-166.

20. Petersen, J., Petersen, N. (1997). K. D. Uschinskij (1824-1870) - ein grosser russischer Pädagoge. Erziehungskunst. Hf. 12, 1229-1236.

Стаття надійшла до редакції 02.12.2019 р. 